Energy and the environment

\title{
Future energy system challenges for Africa: Insights from Integrated Assessment Models
}

\author{
Paul L. Lucas ${ }^{\mathrm{a}, *}$, Jens Nielsen ${ }^{\mathrm{a}}$, Katherine Calvin ${ }^{\mathrm{b}}$, David L. McCollum ${ }^{\mathrm{c}}$, \\ Giacomo Marangoni $^{\mathrm{d}}$, Jessica Strefler ${ }^{\mathrm{e}}$, Bob C.C. van der Zwaan ${ }^{\mathrm{f}, \mathrm{g}, \mathrm{h}}$, Detlef P. van Vuuren ${ }^{\mathrm{a}, \mathrm{i}}$ \\ a PBL Netherlands Environment Assessment Agency, PO Box 303, 3720 BA Bilthoven, The Netherlands \\ b Joint Global Change Research Institute/PNNL, College Park, MD, USA \\ ' International Institute for Applied Systems Analysis (IIASA), Schlossplatz 1, 2361 Laxenburg, Austria \\ ${ }^{\mathrm{d}}$ Fondazione Eni Enrico Mattei (FEEM) and Centro Mediterraneo sui Cambiamenti Climatici (CMCC), Corso Magenta 63, Milan, Italy \\ e Potsdam Institute for Climate Impact Research, PO Box 601203, 14412 Potsdam, Germany \\ ${ }^{\mathrm{f}}$ Energy research Centre of the Netherlands (ECN), Policy Studies, Amsterdam, The Netherlands \\ ${ }^{\mathrm{g}}$ Johns Hopkins University, School of Advanced International Studies, Bologna, Italy \\ h University of Amsterdam, Faculty of Science, Amsterdam, The Netherlands \\ ${ }^{i}$ Copernicus Institute of Sustainable Development, Utrecht University, Heidelberglaan 2, 3584 CS Utrecht, The Netherlands
}

\section{H I G H L I G H T S}

- We assess long-term energy developments in Africa using results of six models.

- Africa's share in global $\mathrm{CO}_{2}$ emissions is projected to increase to $3-23 \%$ by 2100.

- The period before 2050 is critical for the transition towards a low carbon future.

- Without additional policy no universal access to modern energy services by 2030.

- Africa's role as a net fossil fuel exporter is projected to diminish over time.

\section{A R T I C L E I N F O}

Article history:

Received 18 February 2015

Received in revised form

12 August 2015

Accepted 13 August 2015

\section{Keywords:}

Africa

Integrated Assessment Modelling

Energy

Climate policy

Energy access

Energy trade

\begin{abstract}
A B S T R A C T
Although Africa's share in the global energy system is only small today, ongoing population growth and economic development imply that this can change significantly. Here, we discuss long-term energysystem developments in Africa using results of a recent model inter-comparison study on global climate policy. We focus on Africa's role in the wider global energy system and in global climate mitigation. The results show a considerable spread in model outcomes, emphasizing the large uncertainty regarding Africa's energy future. Without climate policy, Africa's share in global energy-related $\mathrm{CO}_{2}$ emissions is projected to increase to $3-23 \%$ by 2100 . Emissions become significant on a global scale only after 2050 . In none of the model projections the international ambition to provide universal modern energy access by 2030 is achieved. Furthermore, although the continent is currently a large net exporter of oil and natural gas, towards 2050 the model projections emphasize that Africa needs most of its resources for its rapidly growing domestic demand. However, the projected rapid expansion of their energy system also implies that Africa gains importance in global mitigation action. An important challenge is to align the increasing investments in the energy system with climate policy and potential revenues from international carbon trading.
\end{abstract}

(c) 2015 Elsevier Ltd. All rights reserved.

\footnotetext{
* Corresponding author.

E-mail addresses: paul.lucas@pbl.nl (P.L. Lucas), jens.jielsen@pbl.nl (J. Nielsen), katherine.calvin@pnnl.gov (K. Calvin), mccollum@iiasa.ac.at (D. L. McCollum), giacomo.marangoni@feem.it (G. Marangoni), strefler@pik-potsdam.de (J. Strefler), vanderzwaan@ecn.nl (B.C.C. van der Zwaan), detlef.vanvuuren@pbl.nl (D.P. van Vuuren).
}

\section{Introduction}

Africa's shares in global energy use and related $\mathrm{CO}_{2}$ emissions are currently relatively small. In 2009, the continent was responsible for around 5.9\% of total global energy use (including modern and traditional energy sources) and $3.2 \%$ of the related 
$\mathrm{CO}_{2}$ emissions (IEA, 2010; UNCTAD, 2012). Furthermore, in 2008, only a small number of nations accounted for the majority of $\mathrm{CO}_{2}$ emissions (South Africa and the North African nations together were responsible for $84 \%$ of the total energy-related $\mathrm{CO}_{2}$ emissions) and only 4 out of the 54 African nations had per capita emissions higher than the global average (Boden et al., 2011). The small shares in global energy use and $\mathrm{CO}_{2}$ emissions are related to relatively low levels of economic activity and low levels of access to modern sources of energy, especially in Sub-Saharan Africa (Mandelli et al., 2014). In fact, Africa's share of the population without access to electricity and modern fuels for cooking and heating is the largest in the world (Pachauri et al., 2013). Furthermore, where several countries in Africa, including Nigeria, Libya and Algeria, are endowed with large fossil fuel resources and are net exporters of oil and natural gas (UNECA, 2011), most other countries are net importers, having serious energy security issues (Bacon and Mattar, 2005). Driven by ongoing population growth, urbanisation and economic development, Africa's energy situation is likely to change significantly (Canadell et al., 2009; Bazilian et al., 2012; Calvin et al., 2013; IEA, 2014; Panos et al., 2015). Expanding their energy system and increasing access to modern sources of energy provides great opportunities to reduce poverty and accelerate economic growth. However, depending on the fuel choice this could also have environmental impacts at the local, regional and global scale, including an increasing regional contribution to global greenhouse gas emissions (Calvin et al., 2013) and air pollution (Liousse et al., 2014).

There are ample studies that have assessed developments in the energy system at the global scale, many focussing on climate change (recent examples include Kriegler et al. (2013a, 2014) and Riahi et al. (2014)). Recent studies have also focussed on specific regions, including Europe (Knopf et al., 2013), Asia (Calvin et al., 2012; Gambhir et al., 2013; Johansson et al., 2014), Latin America (Calvin, 2013; van der Zwaan et al., forthcoming) and large economies (Van Sluisveld et al., 2013). At the same time, few studies have focussed on projections for the African continent. A study by Calvin et al. (2013) forms an important exception. This study addresses how population and economic growth, as well as climate policy, could potentially transform Africa's energy system, including energy access and $\mathrm{CO}_{2}$ emissions. Furthermore, IEA (2014) provides a comprehensive study of future developments in the Sub-Saharan African energy sector and Panos et al. (2015) discuss two alternative scenarios of Sub-Sahara Africa's energy future with a focus on the power sector and grid extension. There are also several studies that address specific elements of Africa's future energy development, including the power sector (IRENA, 2012), renewable energy (IRENA, 2011) and energy access (Brew-Hammond, 2010; Bazilian et al., 2012). Finally, some national scenario studies exist, including for South Africa (Winkler et al., 2011; Alton et al., 2014) and Nigeria (Gujba et al., 2011). None of these studies, however, specifically focusses on Africa's long-term role in the global energy system and global climate change mitigation.

In this context, the current paper analyses long-term developments in Africa's energy system using the results of a recent multi-model scenario study (LIMITS; Kriegler et al., 2013a). The analysis looks specifically at the position of Africa in the wider global energy system and in global climate mitigation. The paper addresses the following questions:

- How does Africa's energy system evolve assuming a continuation of current policies and trends and what does that mean for its shares in global energy use and $\mathrm{CO}_{2}$ emissions?

- How does Africa's future energy system change under globally coordinated climate policy that aims at limiting global mean temperature increase to a maximum of $2{ }^{\circ} \mathrm{C}$ compared to preindustrial levels?
- What do these trends imply for Africa's international trade in energy resources and for household access to modern sources of energy?

The use of multiple models - that differ in model structure, data sources and basic assumptions - allow us to assess the robustness of the projected developments.

The paper is structured as follows. Section 2 describes the methodology, including the two scenarios, and gives a brief description of the models used. Section 3 discusses long-term developments in Africa's energy system, with and without climate policy, including energy supply, energy-related $\mathrm{CO}_{2}$ emissions, energy poverty and trade in primary energy resources. Additionally, this section compares African developments with global developments. Section 4 then discusses some major uncertainties in the model projections and missing issues in the models used. Finally, Section 5 draws some policy and modelling conclusions from the analysis.

\section{Methodology}

For our analysis, we use the model results of the recent LIMITS model inter-comparison study (Kriegler et al., 2013a; Tavoni et al., 2013). The LIMITS study assesses post-2020 climate policies that are broadly consistent with the objective of keeping global mean warming below $2{ }^{\circ} \mathrm{C}$ since preindustrial levels. The study reported on a range of topics relevant in this context, including distributional impacts of climate mitigation, the role of investments and financing, energy security, regional mitigation effort, technology diffusion and bioenergy (Kriegler et al., 2013b). However, no special attention was paid to Africa. Nevertheless, all models used describe future energy system developments for different world regions, together covering the whole world. Here, we only use the results for Africa for a selection of indicators and compare them, where relevant, to the global results. ${ }^{1}$ We mainly discuss model ranges to address the uncertainties and trends with respect to Africa's long-term energy-system developments and only go into individual model results where relevant for drawing conclusions.

The LIMITS projects uses seven energy-economy and Integrated Assessment Models for their analysis. We use the model results of six of them: GCAM (Calvin, 2011), IMAGE (van Vuuren, 2007; Stehfest et al., 2014), MESSAGE (Riahi et al., 2007, 2012), REMIND (Luderer et al., 2011), TIAM-ECN (Keppo and van der Zwaan, 2012, 2013; Rösler et al., 2014) and WITCH (Bosetti et al., 2006, 2009). ${ }^{2}$ Table 1 provides some key model characteristics as a summary. The diversity in model structure and assumptions allows us to take into account several relevant uncertainties related to energy projections as well as drawing more robust conclusions on potential future developments. The models describe future emissions in energy and land use on the basis of expected trends over time for population, income, lifestyle, technology development and resource depletion. Although applied differently across the models, in principle they assume that low cost energy options are used more than high costs options. Climate policy is implemented by forcing the model to limit total greenhouse gas emissions, leading to an implicit or explicit 'greenhouse gas price'. As our intention is not to go into individual model outcomes, we do not give an in-depth description of the models here. For an overview of model details see the overview paper of the LIMITS

\footnotetext{
${ }^{1}$ All scenario results discussed in this paper can be found in the publicly available LIMITS Scenario Database: https://secure.iiasa.ac.at/web-apps/ene/LIM ITSDB/.

2 Results for AIM-Enduse, which was also part of the LIMITS project, are excluded in our analysis as the model does not run up to 2100 .
} 
Table 1

Regional grouping of Africa in the different models and key model characteristics.

\begin{tabular}{|c|c|c|c|c|}
\hline \multirow[t]{2}{*}{ Model } & \multicolumn{2}{|l|}{ Regional grouping } & \multicolumn{2}{|c|}{ Key model characteristics } \\
\hline & Sub-Saharan Africa ${ }^{a}$ & African continent & Model category & Solution methodology ${ }^{c}$ \\
\hline IMAGE & $x$ & $x$ & Partial equilibrium & Recursive dynamic \\
\hline REMIND & $\mathrm{x}$ & & General equilibrium & Intertemporal optimization \\
\hline MESSAGE & $X^{d}$ & & General equilibrium & Intertemporal optimization \\
\hline WITCH & $\mathrm{x}$ & & General equilibrium & Intertemporal optimization \\
\hline GCAM & & $\mathrm{X}$ & Partial equilibrium & Recursive dynamic \\
\hline TIAM-ECN & & $\mathrm{X}$ & Partial equilibrium & Intertemporal optimization \\
\hline
\end{tabular}

a Sub-Saharan Africa excludes the Republic of South Africa and the North African countries.

${ }^{\mathrm{b}}$ General equilibrium models describe the full macro-economic feedbacks of changes in the energy system. Partial equilibrium models focus on the energy and/or landuse system and describe the direct impacts within these sectors.

${ }^{\mathrm{c}}$ Intertemporal optimization models allow for a full minimization of energy system costs or macro-economic losses over time, while in recursive dynamic models only information from previous time-steps is used to make decisions.

${ }^{d}$ Includes the Republic of South Africa and excludes North and South Sudan.

project (Kriegler et al., 2013a) and its supplementary material, as well as more specific model descriptions provided in the papers cited above.

The models have a different sub-division for the African continent, with most models including either the whole continent in one region or address the whole of Sub-Saharan Africa as a region. Therefore, in our comparison they are divided in two groups: models that specifically address Sub-Saharan Africa (excluding North Africa) and models that address the whole African continent in a single region (see Table 1 for an overview). ${ }^{3}$ Only the IMAGE model is represented in both groups as it divides Africa in five regions, thereby creating the possibility of including both aggregates.

The LIMITS study explored different scenarios to assess what would be required to meet the $2{ }^{\circ} \mathrm{C}$ target (Kriegler et al., 2013b). In our analysis, we focus on two scenarios from this project:

1. The Baseline scenario, that assumes that no new climate policies are implemented. Assumptions on the development of trends in socio-economic parameters, energy and land-use and derived emissions were left to the individual modelling teams.

2. The RefPol-450 scenario, that aims at limiting the increase of global mean temperature to a maximum of $2{ }^{\circ} \mathrm{C}$ compared to pre-industrial levels, starting from the Copenhagen Accord pledges in 2020.

The RefPol-450 scenario aims to achieve a radiative forcing target of $2.8 \mathrm{~W} / \mathrm{m}^{2}$ in 2100 , resulting in a likely ( $>66 \%$ ) chance of meeting the $2{ }^{\circ} \mathrm{C}$ target (Meinshausen et al., 2006; Rogelj et al., 2011). The scenario assumes the implementation of lenient climate policy through 2020, based on the submitted reduction proposals (pledges) and mitigation actions included in the Appendices of the Copenhagen Accords (UNFCCC, 2009) and later 'anchored' in the 2010 Cancún Agreements (UNFCCC, 2010a, b). For Africa, this includes a $20 \%$ renewable energy share in total electricity production in North Africa, and 17\% reduction in total GHG emissions ${ }^{4}$ compared to baseline emissions in the Republic of South Africa (Kriegler et al., 2013a). A number of other African countries have submitted nationally appropriate mitigation actions (NAMAs)

\footnotetext{
${ }^{3}$ Formally, Sub-Saharan Africa includes all countries South of the Sahara. The United Nations uses Sub-Saharan Africa to indicate all of Africa except northern Africa, with the Sudan included in North Africa (UN, 2013). Only MESSAGE follows this definition. REMIND and WITCH include Sudan and exclude the Republic of South Africa in their regional definition of Sub-Saharan Africa. We also apply this grouping for IMAGE. Thus, when we discuss results for Sub-Saharan Africa in this paper we refer to Africa without Northern Africa and the Republic of South Africa.

${ }^{4}$ Total GHG emissions include Land-use, Land-use Change and Forestry (LULUCF).
}

under the Copenhagen Accord (UNFCCC, 2013), but as many of the reported actions are difficult to fully quantify, they are not considered in the scenario. After 2020, the RefPol-450 scenario assumes global coordinated mitigation action through a uniform global carbon tax, including global when, where and what flexibility. As such, the model results show the changes in the African energy system in order to reach the $2{ }^{\circ} \mathrm{C}$ climate target, from a global optimal-cost perspective. We do not discuss the required costs of meeting the climate target. For an overview of the associated energy investment requirements see McCollum et al. (2013), and for a discussion of costs relating to different burden sharing schemes see Tavoni et al. (2013) and Kober et al. (2014).

\section{Results}

\subsection{Baseline developments}

The Baseline projections of energy-related $\mathrm{CO}_{2}$ emissions show a large increase between 2010 and 2100, ranging between a factor 7 and 50 over the different models (Fig. 1). To understand the dynamics underneath this increase, we use the well-known Kaya identity (Kaya, 1990) to decompose developments in the energyrelated $\mathrm{CO}_{2}$ emissions in its different drivers:

$$
\begin{aligned}
\mathrm{CO}_{2} \text { Emissions }= & \text { Population } \\
& *(\mathrm{GDP} / \text { Population }) *(\text { Energy/GDP }) \\
& *(\mathrm{CO} 2 / \text { Energy }) .
\end{aligned}
$$

Population and income (per capita GDP in market exchange rates) are important drivers of energy demand and $\mathrm{CO}_{2}$ emissions. Total primary energy demand is further driven by developments in the energy intensity (total primary energy use per unit GDP), while total $\mathrm{CO}_{2}$ emissions are further driven by the carbon intensity (total $\mathrm{CO}_{2}$ emissions per unit primary energy use). Fig. 1 shows future developments for the four subcomponents, total primary energy use and $\mathrm{CO}_{2}$ emissions for the Baseline scenario.

\subsubsection{Population}

The first component, population, is projected to grow rapidly for the African continent as whole and even more for Sub-Saharan Africa. The population is projected to increase from about 1 billion people in 2010 to $1.9-2.7$ billion by 2100 in the models that represent continental Africa (factor $2-3$ increase) and from around 0.8 billion people in 2010 to $2.4-3.3$ billion in 2100 in the models 

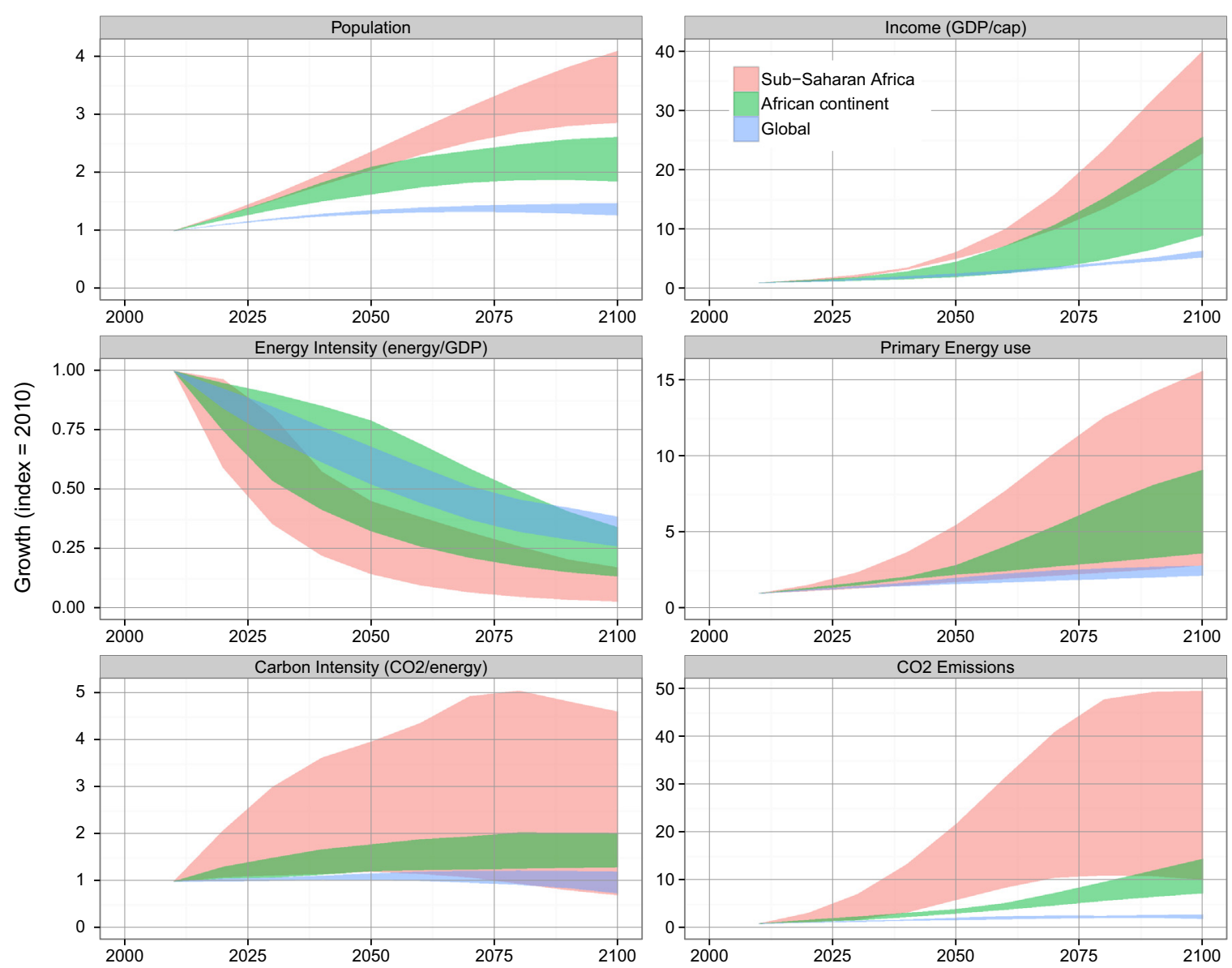

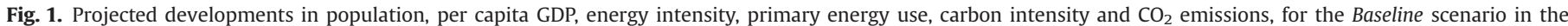
different models.

\section{Table 2}

African shares in global population, GDP, primary energy use and $\mathrm{CO}_{2}$ emissions for the Baseline scenario.

\begin{tabular}{|c|c|c|c|c|}
\hline & & $2010^{\mathrm{a}}$ & $2050^{a}$ & $2100^{a}$ \\
\hline \multirow{4}{*}{ African continent } & Population & $15 \%[15-15 \%]$ & $21 \%$ [19-23\%] & $26 \%$ [22-28\%] \\
\hline & GDP & $2 \%[2-2 \%]$ & $4 \%[3-6 \%]$ & $8 \%[5-14 \%]$ \\
\hline & $\begin{array}{l}\text { Primary energy } \\
\text { use }\end{array}$ & $6 \%[5-6 \%]$ & $8 \%[8-8 \%]$ & $14 \%[10-18 \%]$ \\
\hline & $\mathrm{CO}_{2}$ emissions & $4 \%[3-4 \%]$ & $7 \%$ [7-8\%] & $14 \%$ [10-19\%] \\
\hline \multirow[t]{4}{*}{ Sub-Saharan Africa } & Population & $12 \%[12-12 \%]$ & $20 \%[18-21 \%]$ & $30 \%$ [25-33\%] \\
\hline & GDP & $1 \%[1-2 \%]$ & $5 \%$ [4-6\%] & $15 \%$ [13-18\%] \\
\hline & $\begin{array}{l}\text { Primary energy } \\
\text { use }\end{array}$ & $3 \%$ [3-3\%] & $7 \%[3-10 \%]$ & 13\% [3-19\%] \\
\hline & $\mathrm{CO}_{2}$ emissions & $1 \%[1-3 \%]$ & $7 \%$ [2-9\%] & $12 \%$ [3-23\%] \\
\hline
\end{tabular}

a Median of shares over the different models. The numbers in brackets are the minimum and maximum values.

that represent Sub-Saharan Africa (factor 3-4 increase). ${ }^{5}$ This large increase is primarily due to current and projected high fertility rates. In the 2005-2010 period total births per women in SubSaharan Africa and continental Africa were 5.4 and 4.9, respectively, which is more than double the replacement level. Under medium assumptions, Africa's fertility rate is only expected to

\footnotetext{
${ }^{5}$ As the models use different population projections, the Sub-Saharan Africa projections can surpass the projections used in the models that represent the African continent as a whole.
}

reach the replacement level near the end of the century (UNDESA, 2013). Given the much slower population growth in other parts of the world, Africa's share in the global population is projected to moreover double between 2010 and 2100, from $12-15 \%$ to $22-33 \%$, respectively (see Table 2). In the latest UN World Population Projection, Africa's population is projected to rise even further, reaching 4.2 billion people by 2100 ( 3.1 to 5.7 billion with probability of $95 \%$ ), which is $39 \%$ of the global population (UNDESA, 2013; Gerland et al., 2014).

\subsubsection{Income}

The second component, per capita GDP in market exchange rates, grows much faster than the population, in all model projections. Total growth ranges between a factor 9 and 26 in between 2010 and 2100 in continental Africa (from 900-1200 US $\$$ /cap in 2010 to $8200-30,000$ US\$/cap in 2100) and between a factor 23 and 40 over the same period in Sub-Saharan Africa (from 650-1000 US\$/cap in 2010 to 17,000-28,000 US\$/cap in 2100). It should be noted that the 2100 income levels in Africa are still mostly below the 2010 OECD average of 28,000-32,000 US\$/cap. Nevertheless, the projected per capita GDP growth rates for Africa are much higher than the global growth rates, and as a result, Africa's share in global GDP is projected to increase from 1-2\% in 2010 to $5-18 \%$ in 2100 (see Table 2).

\subsubsection{Energy intensity}

The third component, energy intensity, is projected to decrease significantly. Between 2010 and 2100, the decrease is 66-86\% in continental Africa and 83-97\% in Sub-Saharan, which is much more than is projected globally (61-77\%). This large improvement can be 
a

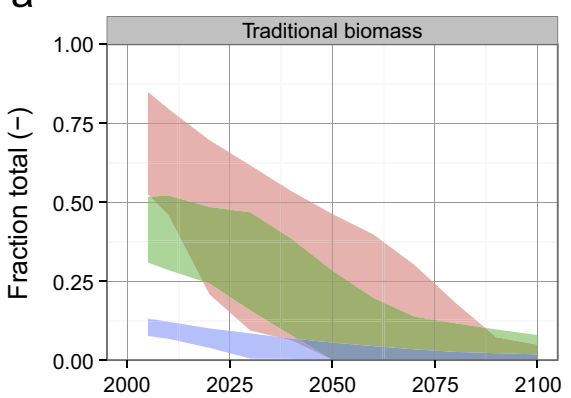

b

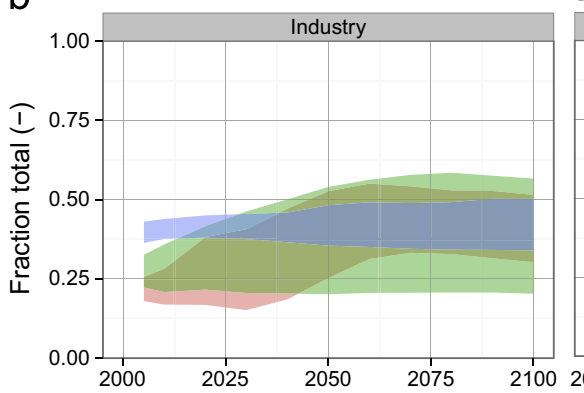

Secondary energy use by fuel type

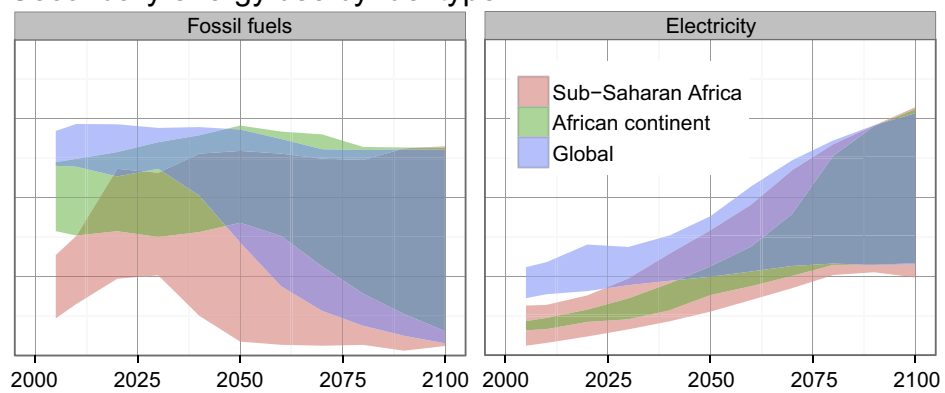

Secondary energy use by sector

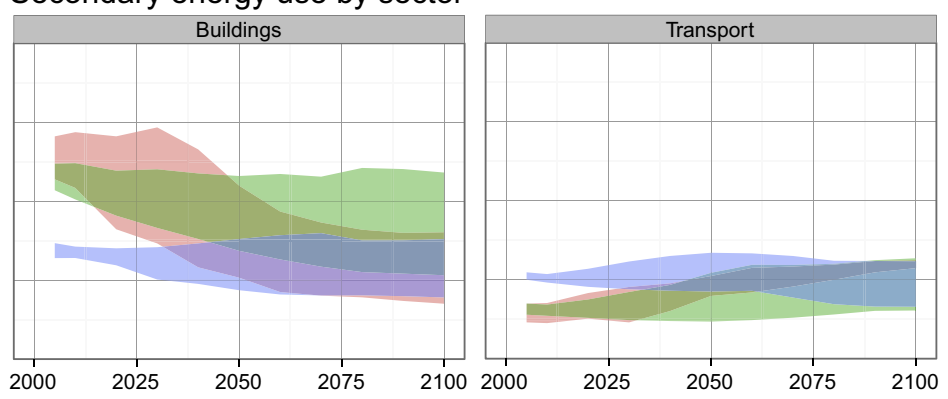

Fig. 2. Projected developments in secondary energy use by fuel type (panel a) and by sector (panel b), for the Baseline scenario in the different models.
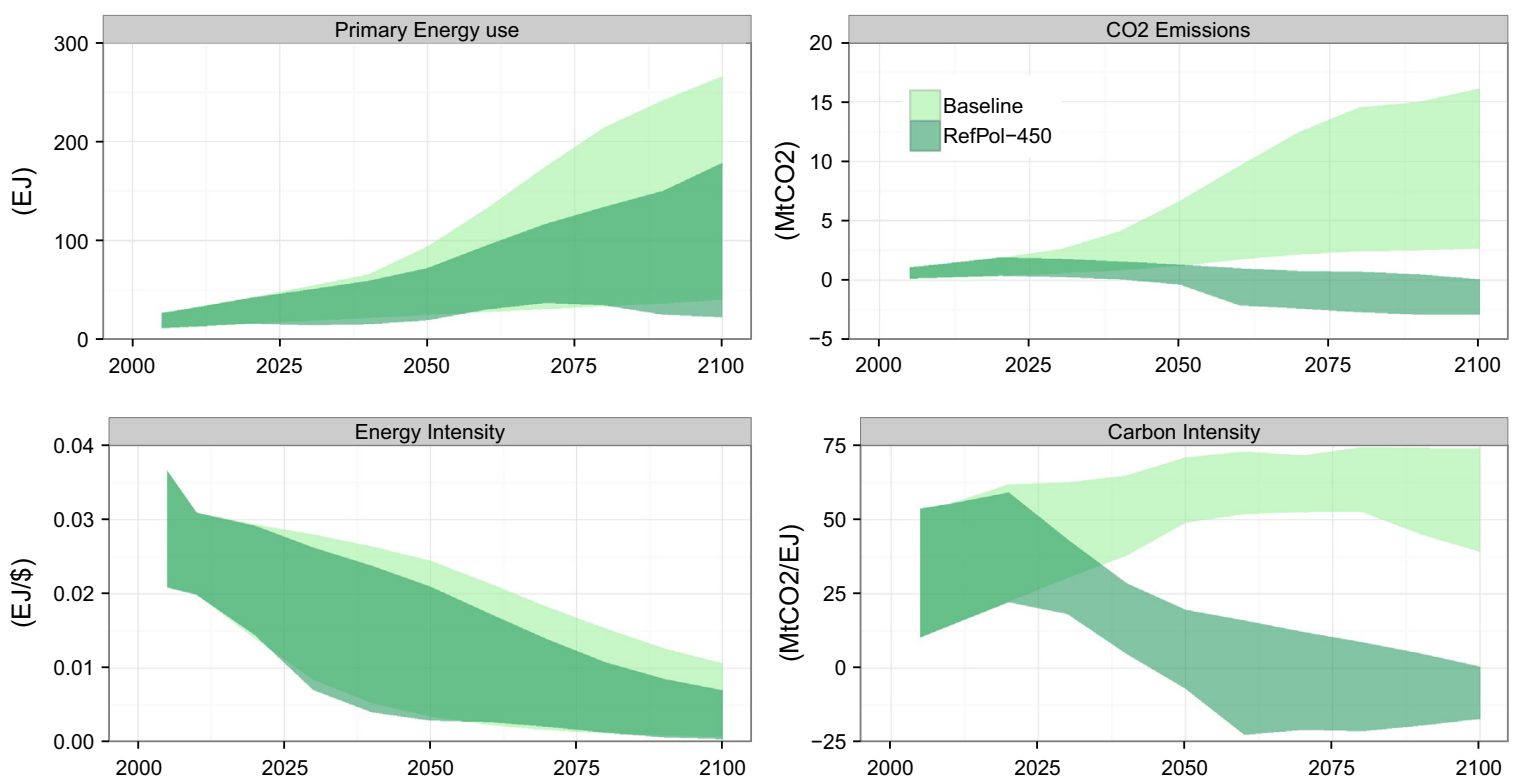

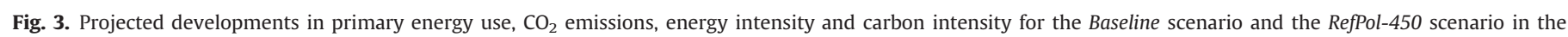
different models.

explained by decreasing dependence on traditional biomass, ${ }^{6}$ increasing electrification of the economy and increasing importance of more efficient sectors such as transport and industry (see Fig. 2). In 2010, the secondary energy mix was dominated by traditional biomass. Furthermore, the electricity share was close to zero in SubSaharan Africa and around 10\% in continental Africa, which was much lower than the global average. In the same year, the buildings sector was the most dominant energy user, primarily for residential

\footnotetext{
${ }^{6}$ Traditional biomass is generally used in open fires and rudimentary stoves with very low conversion efficiency, typically around 15\%, while modern fuels like LPG and natural gas have a much higher conversion efficiency, typically around 60\% (Daioglou et al., 2012).
}

use, with shares being almost twice the global average. Towards 2050, these shares are projected to change significantly, and by 2100 traditional biomass use is almost completely phased out, electricity has become the most dominant secondary energy source and the shares of transport and industry in total secondary energy use have grown towards the global average.

Despite the large efficiency improvements, total primary energy use is projected to increase from 11 to $15 \mathrm{EJ} / \mathrm{year}$ in 2010 in Sub-Saharan Africa and 22 to $26 \mathrm{EJ} /$ year in continental Africa, to $40-266 \mathrm{EJ} /$ year and $104-220 \mathrm{EJ} /$ year by 2100 , respectively. This is much faster than the global total. As a result, Africa's share in total global primary energy use is projected to increase from 3-6\% in 2010 to $10-19 \%$ in 2100 (see Table 2). 
Table 3

Decomposition of cumulative $2010-2100 \mathrm{CO}_{2}$ emission reductions in the RefPol-450 scenario compared to the Baseline scenario. GDP effects are only accounted for in the general equilibrium models (REMIND, MESSAGE and WITCH). As a result, median values for the shares of the energy intensity and carbon intensity improvements are larger for the models that do not include this effect and the sum of the three shares exceeds $100 \%$.

\begin{tabular}{|c|c|c|c|c|c|}
\hline & \multirow[t]{2}{*}{ Unit } & \multicolumn{2}{|l|}{ Africa $^{a, b}$} & \multicolumn{2}{|l|}{ Global $^{\mathrm{a}}$} \\
\hline & & 2010-2050 & 2050-2100 & 2010-2050 & 2050-2100 \\
\hline Energy Intensity & $\%$ & 19 [12-37] & $15[-1$ to 21$]$ & $30[20-42]$ & $17[9-28]$ \\
\hline Carbon Intensity & $\%$ & $76[58-85]$ & 85 [76-99] & $68[53-80]$ & 82 [67-91] \\
\hline $\mathrm{GDP}^{\mathrm{a}}$ & $\%$ & $10[5-12]$ & $2[1-3]$ & $3[2-5]$ & $2[1-4]$ \\
\hline
\end{tabular}

${ }^{\text {a }}$ Median of shares over the different models. The numbers in brackets are the minimum and maximum values.

${ }^{b}$ These ranges cover both the results for Sub-Saharan Africa and continental Africa.

\subsubsection{Carbon intensity}

Finally, projections for the fourth component, the carbon intensity, range between staying moreover constant at 2010 levels (or even decrease) to an increase by a factor 2 in continental Africa and a factor 5 in Sub-Saharan Africa, between 2010 and 2100. This increase is primarily the result of large growth in fossil fuel consumption, much larger than the growth in the consumption of
10-50 in Sub-Saharan Africa and a factor 7-15 in continental Africa. ${ }^{7}$ This significant increase in $\mathrm{CO}_{2}$ emissions results in an increasing African share in global $\mathrm{CO}_{2}$ emissions from $1-4 \%$ in 2010 to $3-23 \%$ in 2100 (see Table 2). Besides WITCH, all models project 2100 shares above $10 \%$. This concludes that, in order to reach stringent long-term climate targets such as the $2{ }^{\circ} \mathrm{C}$ target, future energy developments in Africa should not be overlooked.

\subsection{Developments under stringent climate policy}

Fig. 3 shows absolute projections for primary energy use and $\mathrm{CO}_{2}$ emission, as well as for the energy intensity and the carbon intensity, for both the Baseline and the RefPol-450 scenario. Results for continental and Sub-Saharan Africa are grouped together. In all model projections, global coordinated climate policy results in a small decrease in the energy intensity and a large decrease in the carbon intensity. As a result, energy demand reduces slightly, while related $\mathrm{CO}_{2}$ emissions go negative during the second half of the century.

Table 3 presents a decomposition of cumulative emission reductions related to improvements in the energy intensity, improvements in the carbon intensity and changes in GDP, using an additive decomposition techniques of the Kaya identity (Steckel et al., 2011). Improvements in carbon intensity (i.e. shifts in energy supply) for the 2010-2050 period accounts for three quarters of the emission reductions in the African regions and for around two-
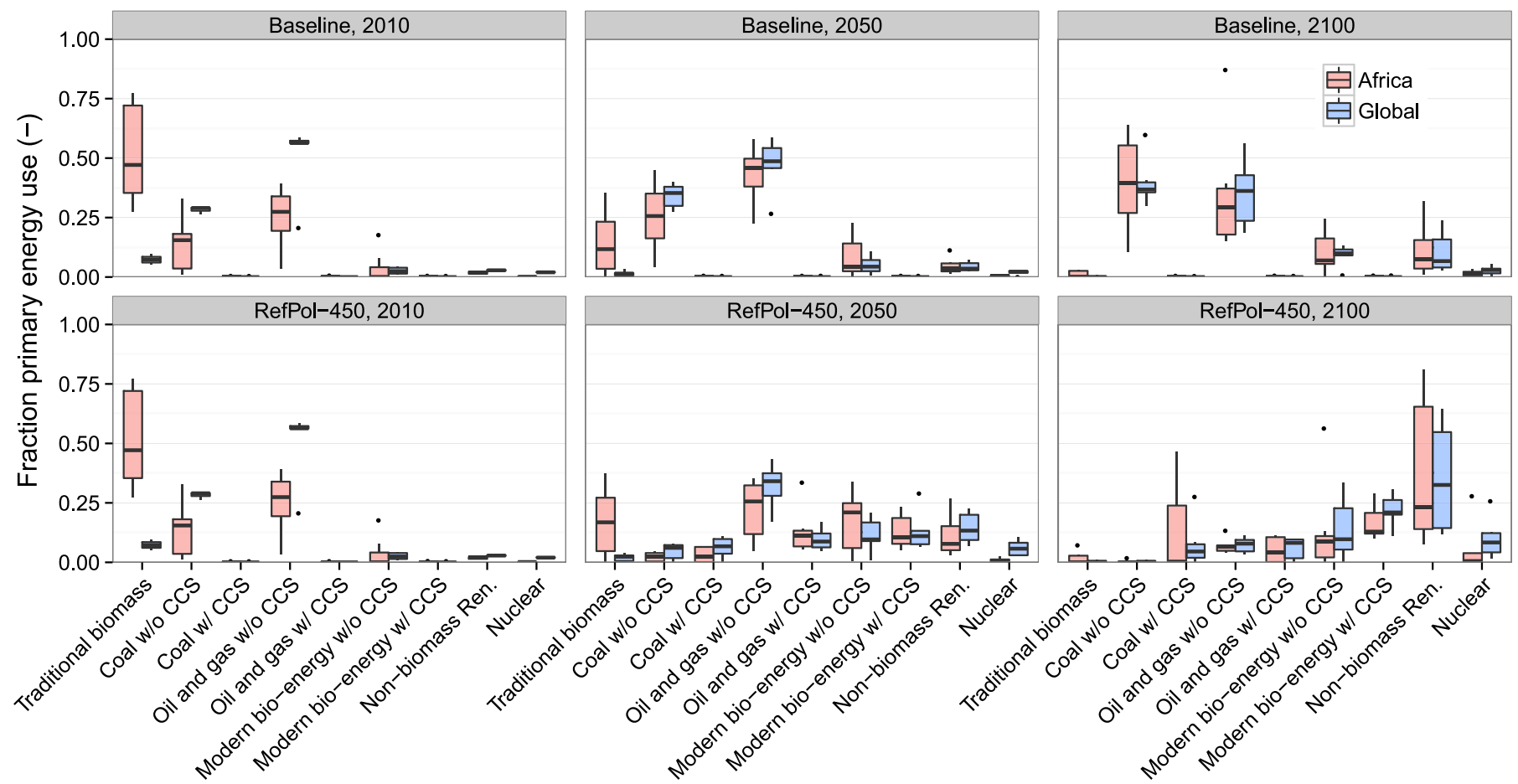

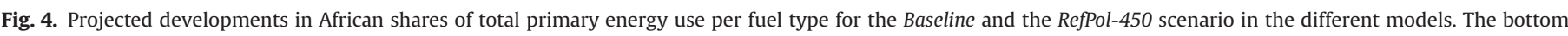

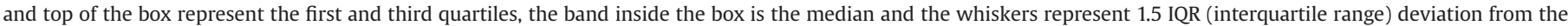
box. Data outside 1.5 IQR from the box are represented as individual dots.

modern bio-energy and non-biomass renewables. Between 2010 and 2100 , fossil fuel shares are project to increase from $8 \%$ to $24 \%$ in Sub-Saharan Africa and 50\% to 57\% in continental Africa, to $41-$ $98 \%$ and $72-82 \%$, respectively (see also Fig. 4). Overall, the share of fossil fuels in total primary energy demand grows towards the world average in 2100.

Combining all four components shows an increase in total energy-related $\mathrm{CO}_{2}$ emissions between 2010 and 2100, with a factor third globally. In the second half of the century these shares increase to around $85 \%$ for both Africa and globally. The remainder is

${ }^{7}$ REMIND is a notable exception, where the consumption of traditional biomass is phased out much faster than in the other model projections and replaced by fossil fuels, primarily coal, thereby significantly increasing the carbon intensity in the short term and resulting in an increase of $\mathrm{CO}_{2}$ emissions of a factor 22 between 2010 and 2050. 
Table 4

Relevant climate policy indicators for the Baseline and the RefPol-450 scenario.

\begin{tabular}{|c|c|c|c|c|c|c|}
\hline \multirow[t]{2}{*}{ Indicator } & \multirow[t]{2}{*}{ Unit } & \multirow[t]{2}{*}{ Period } & \multicolumn{2}{|l|}{ Baseline } & \multicolumn{2}{|l|}{ RefPol-450 } \\
\hline & & & Africa $^{a}$ & World & Africa $^{a}$ & World \\
\hline \multirow[t]{2}{*}{ Emissions increase compared to $2005^{\mathrm{b}}$} & $\%$ & 2030 & 397 [191-1133] & $162[149-182]$ & 215 [124-606] & $100[71-126]$ \\
\hline & $\%$ & 2050 & 1011 [395-3457] & 155 [138-179] & $95[-98$ to 353$]$ & $29[17-53]$ \\
\hline \multirow{2}{*}{ Per capita emissions ${ }^{\mathrm{b}}$} & $\mathrm{tCO}_{2} / \mathrm{cap}$ & 2030 & $1.3[0.4-1.9]$ & $5.6[5.3-6.1]$ & $0.7[0.2-1.3]$ & $3.5[2.4-4.4]$ \\
\hline & $\mathrm{tCO}_{2} / \mathrm{cap}$ & 2050 & $2.2[0.6-3.5]$ & $6.7[5.9-7.9]$ & $0.3[-0.2$ to 0.8$]$ & $1.2[0.7-2.3]$ \\
\hline Annual reduction rate e $^{\mathrm{b}, \mathrm{c}}$ & $\% /$ Year & 2020-2050 & - & - & $1.1[-0.9$ to 4.5$]$ & $2.4[1.6-2.8]$ \\
\hline \multirow[t]{2}{*}{ Reduction compared to Baseline level ${ }^{\mathrm{b}}$} & $\%$ & 2030 & - & - & $44[27-63]$ & $37[25-61]$ \\
\hline & $\%$ & 2050 & - & - & 90 [69-111] & 83 [68-91] \\
\hline Peak year of emissions & Year & - & $>2080$ & $>2070$ & $2020-2060$ & 2020 \\
\hline Year emissions go negative & Year & - & - & - & 2040-2090 & $2060-2070$ \\
\hline \multirow[t]{2}{*}{ Cumulative reduction share of total $2010-2100$ reductions $^{\mathrm{b}}$} & $\%$ & $2010-2050$ & - & - & $5[3-8]$ & $18[14-23]$ \\
\hline & $\%$ & $2050-2100$ & - & - & 95 [92-97] & $82[77-86]$ \\
\hline Average annual investments & b\$/year & 2010-2050 & $75-81^{d}$ & $1017-1348^{d}$ & $59-243$ & $1292-3202$ \\
\hline
\end{tabular}

a These ranges cover both the results for Sub-Saharan Africa and continental Africa.

${ }^{b}$ Median values over the different models. The numbers in brackets are the minimum and maximum values.

${ }^{c}$ As WITCH and MESSAGE already have negative emissions in 2050, average decrease is calculated as average yearly 2020-2050 decrease as percentage of 2020 emissions.

${ }^{d}$ These numbers are recalculated as the Baseline scenario was not included in the study of McCollum et al. (2013). Due to data availability, only results for IMAGE and MESSAGE are shown here.

mainly related to improvements in the energy intensity (efficiency improvements). Only in Africa in the first half of the century reductions in GDP account for around 10\%. The differences between Africa and the global numbers can largely be explained by projected growth in energy demand. Where growth in energy demand is only small to negative in most developed countries, in Africa energy demand is projected to increase over the whole century (Fig. 3). This creates the potential to leap-frog to new technologies instead of replacing existing power plants. The large GDP impacts in Africa are primarily the result of their low per capita GDP levels and reduced income from fossil fuel export due to global climate policy (see also Section 3.3).
Fig. 4 shows the shares of different fuel types in total primary energy use for the Baseline and the RefPol-450 scenario, globally and in Africa. As a result of globally coordinated climate policy, fossil fuel use without CCS (especially coal) is gradually phased out and replaced by non-biomass renewables and bio-energy with and without CCS. The share of Nuclear energy also increases, but remains marginal compared to the other sources. Coal with CCS is not applied in most model projections (only IMAGE does), primarily due to the lack of coal reserves in most African countries (see Section 3.3). The share of Oil and gas with CCS increases towards 2050, decreasing slowly afterwards. By 2050, a broad portfolio of technologies is used without any technology being a

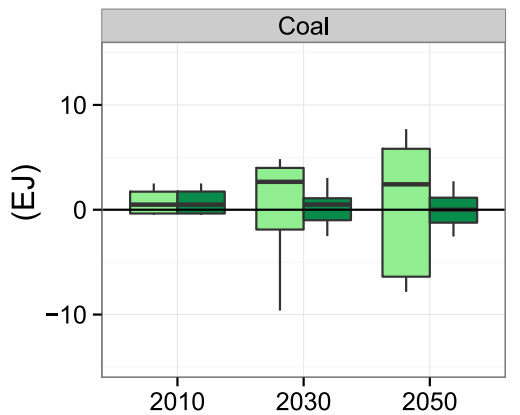

b

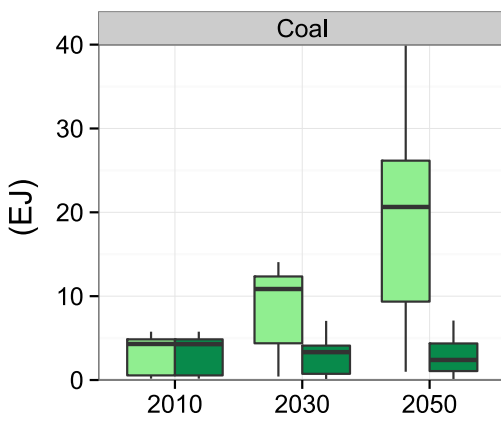

Net trade in energy sources: export (+) and import (-)
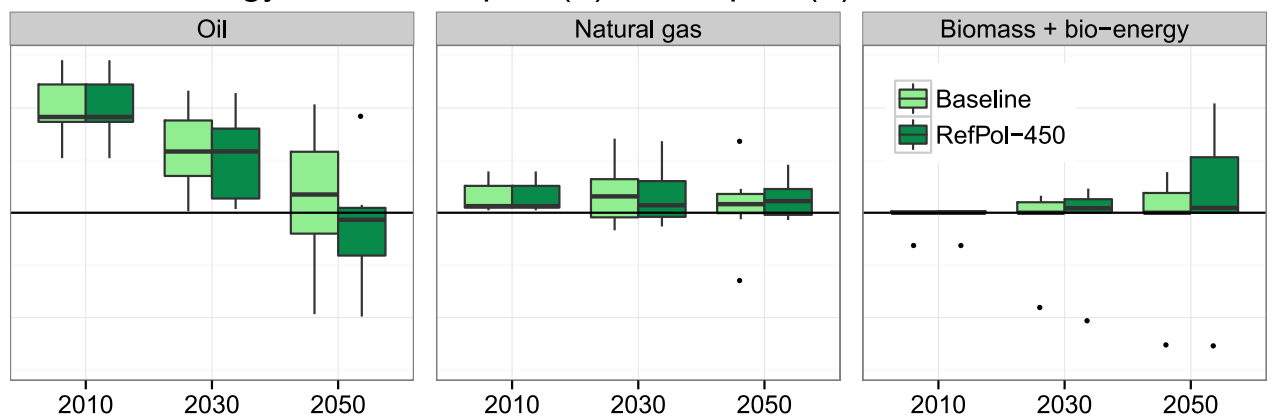

Primary energy use
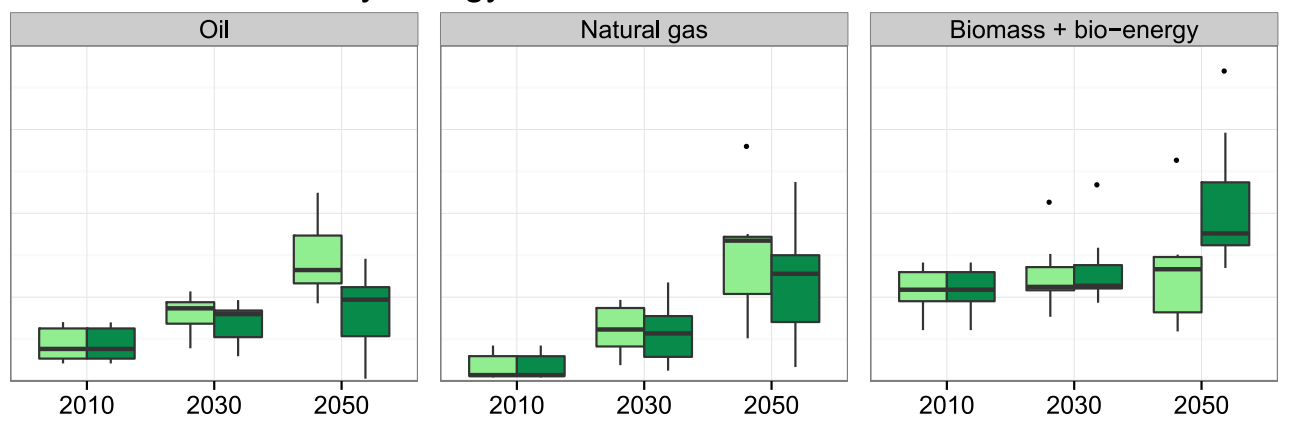

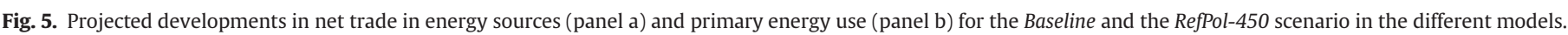

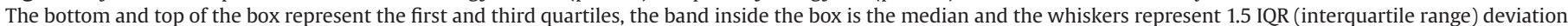
from the box. Data outside 1.5 IQR from the box are represented as individual dots. 
Table 5

African shares in global primary energy production in the Baseline and the RefPol450 scenario.

\begin{tabular}{llll}
\hline & $\mathbf{2 0 1 0}^{\mathrm{a}}$ & $\mathbf{2 0 5 0}^{\mathrm{a}}$ & \\
\cline { 3 - 4 } & & Baseline & RefPol-450 \\
\hline Bio-energy & $22[13-27]$ & $20[12-51]$ & $14[7-30]$ \\
Coal & $4[0-6]$ & $6[0-12]$ & $4[1-8]$ \\
Crude oil & $9[6-12]$ & $6[3-11]$ & $5[1-11]$ \\
Natural gas & $3[1-7]$ & $7[3-11]$ & $8[1-14]$ \\
\hline
\end{tabular}

\footnotetext{
a Median of shares over the different models. The numbers in brackets are the minimum and maximum values.
}

particularly dominant. Towards 2100 , however, the share of nonbiomass renewables grows significantly and becomes the dominant energy source in most model projections. Furthermore, by 2100, the African fuel mix is moreover similar to the global mix, only with much lower shares for CCS and nuclear energy (Clarke et al., 2012; van der Zwaan et al., 2013).

Table 4 summarizes relevant climate policy indicators for Africa and for the world as a whole. Annual 2020-2050 reduction rates ${ }^{8}$ in the RefPol-450 scenario are much lower in Africa than globally, while the reductions compared to the baseline level are moreover in the same range. The primary reason is that Africa's 2020 emissions are still very low and most emission reductions are related to different choices with respect to the extension of their energy system instead of replacement of existing power plants, as is the case in OECD countries. Similar to the global level, emissions in Africa peak already in 2020 in the RefPol-450 scenario, with levels ranging between 1400 and $1900 \mathrm{Mt} \mathrm{CO}_{2}$. Notable exceptions are REMIND where emissions peak in 2030, and IMAGE Sub-Saharan Africa, where emissions steadily increase towards 2060, followed by a rapid decline. Furthermore, the models project $\mathrm{CO}_{2}$ emissions in Africa going negative between 2040 and 2090, resulting from the application of bio-energy with carbon capture and storage (CCS) (see also Fig. 4), which is a much wider timeframe than projected globally (between 2060 and 2070). Only in IMAGE Sub-Saharan Africa $\mathrm{CO}_{2}$ emissions remain positive throughout the century. Finally, only around 5\% of total 2010-2100 cumulative emission reductions in Africa occur in the first half of the century, while globally this is three to four times as much. This concludes that Africa might not be that important for global climate mitigation the coming decades, while after 2050 its role increases.

Current investments in Africa's energy system are estimated to be relatively low compared to other world regions, with by far most of the investments being for fossil fuel extraction (McCollum et al., 2013). Under the Baseline scenario these investments are set to grow, with the largest increase in the power sector to fulfil the increasing demand for electricity of the growing and increasingly affluent population. Under the RefPol-450 scenario the annual 2010-2050 investments are projected to grow further to moreover twice the base-year value, with increases in the power sector, mostly renewable energy, and in energy efficiency. It should be noted the potential financial flows from carbon trade under specific burden-sharing regimes could be far greater (for details see McCollum et al. (2013) and Tavoni et al. (2013)).

An important aspect of mitigation strategies is the timing of emission reductions. Technologies are mostly replaced after their technical lifetime, which is $30-60$ years for most fossil-powered plants (Riahi et al., 2012). Earlier studies for China and India

\footnotetext{
${ }^{8}$ Average yearly 2020-2050 decrease as percentage of 2020 emissions.
}

showed that periods of rapid expansion of the power sector and heavy industry represent an important moment to avoid lock-in into carbon intensive energy systems (Van Ruijven et al., 2012b; Lucas et al., 2013). Increasing demand for energy services also increases infrastructure and installed capacity expansion and thereby the possibility to choose between a fossil-intensive or a renewable energy future. For the Baseline scenario, the models project a rapid expansion in fossil fuel power generation throughout the century, with a peak in absolute increase between 2040 and 2100. This implies that in order to avoid a significant lock-in, the period before 2050 is already critical for long-term climate mitigation.

\subsection{Trade in primary energy sources}

Fig. 5 shows projections in net trade in primary energy sources and primary energy use In Africa. Table 5 presents Africa's current and future shares in global primary energy production. In 2010, Africa's volumes traded were very large compared to domestic use and the continent as a whole was a net exporter of oil and gas. On average, over $70 \%$ of the oil produced and $55 \%$ of the natural gas produced was exported outside the continent (IEA, 2011). In comparison, export of coal is only marginal. Globally, Africa is a relatively small player with respect to fossil fuel production, with on average less than $5 \%$ of the global production of coal and gas and around $9 \%$ of the global crude oil production. On the contrary, the global share in biomass production is more than $20 \%$. Finally, although the continent is well endowed with crude oil, especially Sub-Saharan Africa is severely constrained in refining capacity, resulting in large net import of oil products (IEA, 2014).

Clearly, Africa's fossil fuel resources are not evenly distributed across the continent (BGR, 2013). Around 95\% of the continent's coal reserves are situated in the Republic of South Africa and more than $80 \%$ of the coal resources are situated in Botswana, Mozambique and Zimbabwe. ${ }^{9}$ For natural gas, around $74 \%$ of the combined reserves and resources are situated in only five countries, i.e. Algeria, Egypt, Libya, Nigeria and South Africa. However, recent discoveries of a large natural gas field before the coast of Mozambique and Tanzania could move these two countries to the top 5. Finally, $66 \%$ of the combined oil reserves and resources are situated in only four countries, mostly in Libya and Nigeria. Therefore, although the continent as a whole is a net energy exporter, many individual countries are not.

In the Baseline scenario, demand for fossil fuels is projected to increase steadily, although the model ranges are large. The models

\section{Table 6}

Cumulative consumption versus estimates of conventional and unconventional reserves and resources of fossil fuels in Africa in the Baseline scenario.

\begin{tabular}{|c|c|c|c|c|}
\hline & \multicolumn{2}{|c|}{ Cumulative consumption ${ }^{a}$} & \multirow{2}{*}{$\begin{array}{l}\text { Estimated } \\
\text { conv. re- } \\
\text { serves/ } \\
\text { resources }^{\text {b }}\end{array}$} & \multirow{2}{*}{$\begin{array}{l}\text { Share in global } \\
\text { reserves + res- } \\
\text { ources }^{b}\end{array}$} \\
\hline & 2010-2050 & 2010-2100 & & \\
\hline & EJ & EJ & EJ & $\%$ \\
\hline Coal & 485 [19-591] & 2652 [142-5205] & $851 / 1921$ & 1 \\
\hline Oil & 404 [219-541] & 1224 [879-1942] & $745 / 1302$ & 9 \\
\hline Natural gas & 321 [96-591] & 1601 [666-2590] & $555 / 3084$ & 12 \\
\hline
\end{tabular}

\footnotetext{
${ }^{a}$ Median of projected demand in the different models for the Baseline scenario. Numbers in brackets are minimum and maximum values over the different models b BGR (2013).
}

\footnotetext{
${ }^{9}$ Reserves refer to proven volumes of energy commodities economically exploitable at today's prices and using today's technology, whether conventional or
} 
do not agree whether Africa is a net exporter or a net importer of coal, especially in 2050. The ranges in demand and trade can be explained by differences in model assumptions about resource availability and extraction costs (see also McCollum et al. (2014)). Also the regional grouping plays a role, with the models addressing continental Africa reporting much larger demand than the models addressing Sub-Saharan Africa that exclude the North African countries. The North African countries are well endowed with fossil fuels, especially natural gas, while the Republic of South Africa is well endowed with coal. For oil and natural gas, the models agree that Africa is a net exporter now. However, net oil exports are projected to be reduced to almost zero by 2050. This can be explained by a large increase in demand for oil products, a moderate increase in crude oil production and ongoing constraints in refining capacity, forcing African countries to import oil products like diesel and gasoline. For natural gas, net trade is small and remains relatively constant towards 2050. In conclusion, although the production of oil and natural gas increases significantly, this increase in natural resources is used mostly to satisfy domestic demand. It should be noted that African resources are currently still largely unexplored (Collier, 2010). Furthermore, the models do not fully account for the recent large increases in natural gas reserves in Mozambique and Tanzania. Further exploration and exploitation of recently discovered reserves could significantly increase African export far beyond the current projections.

In the RefPol-450 scenario the observed trends do not change much from the Baseline scenario. However, in absolute numbers both energy use and trade decline for coal and oil. Net trade in natural gas remains similar to the Baseline scenario. Bio-energy shows an opposite trend, where the use increases significantly, although net exports do not change much. Africa's share in global bio-energy production is also projected to decrease compared to the Baseline scenario, probably because production in other regions increases faster.

Table 6 shows cumulative consumption of coal, oil and natural gas for the Baseline scenario and regional estimates of fossil fuel reserves and resources. ${ }^{10}$ Despite the current large oil exports from Western and Northern Africa, Africa as a whole appears not particularly well endowed with fossil resources, especially when compared to the rest of the world. This implies that under the projected increases in energy consumption, cheap resources of oil and natural gas, but also of coal, might easily become depleted, and as a result, Africa might switch from being a net exporting region into becoming a net importing region. Total reserves might suffice to fulfil total cumulative consumption during the first half of the century, but not when also taking the projected exports into account. For oil and natural gas, including the resources might suffice to also fulfil cumulative consumption during the second half of the century, but the projected exports towards 2050 could also force Africa to become a net importer of these fossil fuels. With respect to coal, total resources are not enough in most model projections to fulfil cumulative consumption during the second half of the century. Obviously, a shift towards renewable energy resource could slow down depletion significantly.

\section{(footnote continued)}

unconventional. Resources here refer to proven amounts of energy resources which cannot currently be exploited for technical and/or economic reasons, as well as unproven but geologically possible energy resources which may be exploitable in future.

${ }^{10}$ Estimates of available fossil fuel reserves and resources vary significant in the literature, especially for the unconventional resource. Reserve and resource estimates presented here are from BGR (2013). Rogner et al. (2012) provides a overview using different sources, but the order of magnitute is moreover the same.

\subsection{Energy poverty}

People in developing countries have a range of fuels and technologies to meet their energy requirements. Richer households generally use modern energy sources such as electricity and gaseous fuels, while poorer households largely depend on traditional biomass. With respect to access to modern energy sources, African countries rank among the lowest in the world. In 2010, around $57 \%$ of the population did not have access to electricity and $67 \%$ relied primarily on the use of traditional biomass on inefficient stoves (IEA, 2012). Improving access to modern sources of energy is important for human development. Switching from traditional biomass for cooking and heating to using modern sources like kerosene, LPG or electricity can avoid health impacts from indoor air pollution, especially for children under five, improve income and education opportunities due to reduced time spent on collecting firewood, and reduce environmental impacts such as deforestation and $\mathrm{CO}_{2}$ and black carbon emissions associated with unsustainable firewood collection and burning (Desai et al., 2004; Hutton et al., 2007).

The UN Secretary General's Sustainable Energy for All initiative (SE4All; Yumkella and Holliday, 2012) includes the target to ensure universal access to modern energy services by 2030. This target is also included in the Sustainable Development Goals (SDGs; Nilsson et al., 2013; UN, 2015). Here, we are interested if this target is achieved in the Baseline scenario and the RefPol-450 scenario. However, the models included in this comparison do not explicitly address energy access, with the exception being the IMAGE model (Daioglou et al., 2012; van Ruijven et al., 2012a). ${ }^{11}$ To overcome this we concentrate on developments in the share of traditional biomass in secondary energy use, installed electricity capacity and the residential energy mix (see also Calvin et al. (2013)).

According to the models, the 2010 traditional biomass share in secondary energy use was $71-77 \%$ in Sub-Saharan Africa ${ }^{12}$ and $27-47 \%$ in continental Africa (see Fig. 2). Towards 2030, all models project a decrease, although they do not agree with respect to the speed of this decrease. For Sub-Saharan Africa, REMIND and MESSAGE project a large decrease in the share of traditional biomass use to $26 \%$ and $11 \%$, respectively, while IMAGE and WITCH project a rather small decrease to $58 \%$ and $56 \%$, respectively. For continental Africa the model shares decreases to $12 \%$ to $38 \%$.

Per capita installed electricity capacity was very small in 2010 , i.e. less than $50 \mathrm{~W} /$ cap in Sub-Saharan Africa and 120-130 W/cap in continental Africa. In comparison, 2010 levels in India were around $160 \mathrm{~W} / \mathrm{cap}$, in China around $600 \mathrm{~W} / \mathrm{cap}$ and in OECD countries 1500-3000 W/cap. Bazilian et al. (2012) estimate that ensuring full access to electricity by 2030 (both for direct residential purposes and for economy-wide productive uses) in SubSaharan Africa (excluding South Africa) would require an installed capacity of about $374 \mathrm{GW}$. Only MESSAGE reaches this requirement, but that model includes South Africa in its Sub-Saharan Africa aggregate. The other models addressing Sub-Saharan Africa do not reach levels above $200 \mathrm{GW}$ in 2030 .

Fig. 6 shows shares of different energy sources in residential energy use for the Baseline and the RefPol-450 scenario. Four of the models include a breakdown of residential energy use by fuel type, only WITCH and REMIND do not. In 2010, the share of traditional biomass and the share of electricity in the household energy mix

${ }^{11}$ Also the MESSAGE models has a version that explicitly address energy access (Ekholm et al., 2010; Pachauri et al., 2013), but this version was not used for the study presented here.

12 In MESSAGE the share of traditional biomass in primary energy use is much lower (30\%) as it includes the Republic of South Africa that has a much larger share for coal. 

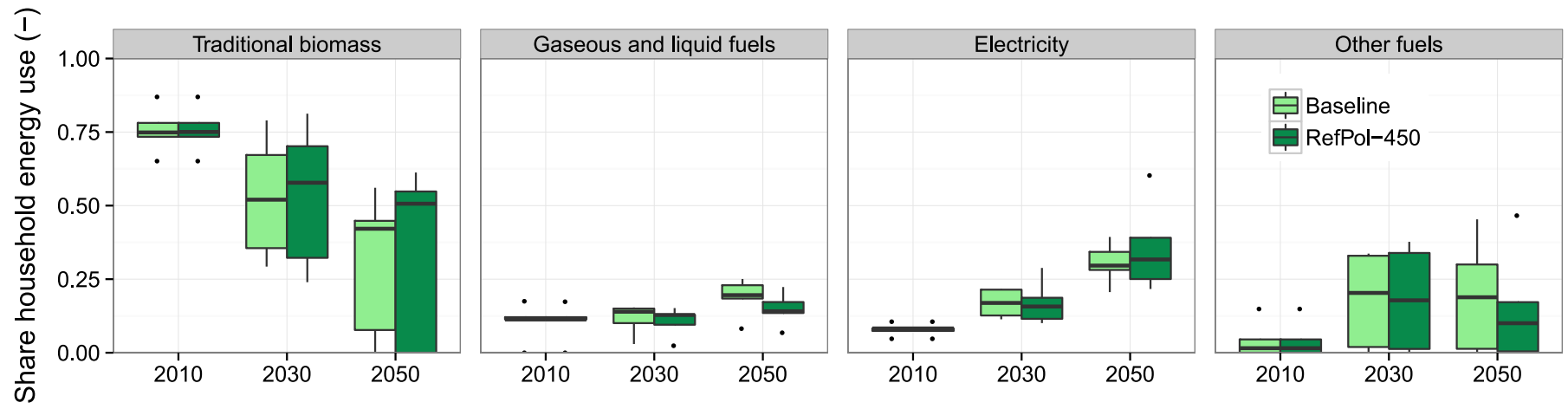

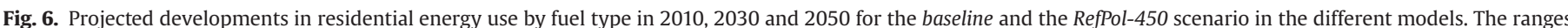

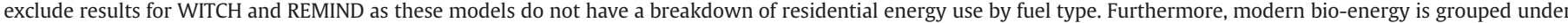

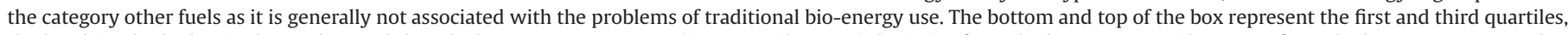

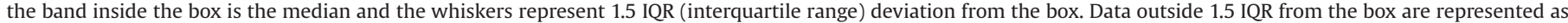
individual dots.

were both globally around 30\%. In Africa, however, household energy use was much more dominated by traditional biomass (65$78 \%$ ), while electricity use was relatively small (7-11\%). In the Baseline scenario, towards 2030, the share of traditional biomass is projected to decrease, while the share of electricity use increases. However, the model spread for the rate of these development differs significantly. Furthermore, there is no clear distinction between developments in Sub-Saharan Africa and in continental Africa. Towards 2050, several models project traditional biomass use to decrease to close to zero (MESSAGE and TIAM-ECN), while other models project absolute use to remain moreover constant, with shares decreasing to around $45 \%$ of total household use (IMAGE and GCAM).

The RefPol-450 scenario shows similar trends and disagreement between the models as the Baseline scenario. In IMAGE and GCAM, models that project a relatively slow transition to modern energy sources, the imposed global carbon tax further slows down this transition. TIAM-ECN and MESSAGE also project a decrease of the use of fossil fuels (gases and liquids), but at the same time an increase in electricity use. ${ }^{13}$ Except for MESSAGE, these results confirm earlier conclusions that increased fossil-fuel prices due to climate policy make the transition away from traditional biomass more difficult for the poorest households (see also Daioglou et al. (2012), Calvin et al. (2013) and Lucas et al. (2013)).

Overall, the model projections conclude that the SE4All target to ensure universal access to modern energy services by 2030 is unlikely to be achieved without additional targeted policies and that climate policy could make the transition even more difficult.

\section{Discussion}

The models mostly agree with respect to the overall trends in the various drivers of energy demand and $\mathrm{CO}_{2}$ emissions, and developments in the shares of different sectors and energy carriers in the energy mix. However, the quantitative results differ largely across the models, pointing at significant uncertainties. For instance, by 2100 , the population projections differs by a factor 2 , per capita GDP by a factor 4 and the carbon intensity by a factor 5 , between the highest and the lowest baseline projection. As a result, also trends in primary energy use and related $\mathrm{CO}_{2}$ emissions show a wide range. Furthermore, the results show clear differences

${ }^{13}$ MESSAGE exogenously induces a faster transition to universal energy access in the RefPol-450 scenario. By 2050, this assumption results in higher levels of electricity use and lower levels of traditional biomass use in this scenario compared to the Baseline scenario. in model dynamics. For example, WITCH and REMIND both have the highest population growth and medium growth in GDP per capita, and GCAM has the lowest growth in both drivers. However, in terms of energy use and related $\mathrm{CO}_{2}$ emissions, REMIND projects the highest values, GCAM medium values and WITCH projects the lowest values. This points to large differences in price and efficiency developments in the models. With respect to trade in coal and bio-energy the models do not only show large differences in magnitude, they also differ with respect to Africa being a net energy exporter or importer. Finally, concerning the share of traditional biomass in the secondary energy mix, the models agree that this reduces over time, but the rate of reduction differs significantly over the models.

There are several factors that contribute to the large spread in model outcomes, including: (i) differences in regional definitions (see Table 1); (ii) differences in base year data and data sources (see also Chaturvedi et al. (2012)); (iii) differences in projections for key drivers, including population, per capita GDP and technology (see also Calvin et al. (2013), and Section 3.1); and (iv) differences in model dynamics. With respect to the last point, it should be noted that the models are different in terms of methodological approaches (top-down CGE models and bottom-up energy system models), the detail in representing energy demand and supply sectors, and the assumptions about techno-economic parameters. In the results section, some differences could be explained by methodological approach, but certainly not all. In general, under a carbon tax, top-down models tend to induce more demand side changes, while bottom-up models induce more carbon intensity reductions (van Vuuren et al., 2009; Johansson et al., 2014). With respect to household energy use, the models also use different methodologies. Of the model versions employed in this study, most utilize an inverse relation of traditional biomass use with per capita income. Only the IMAGE model explicitly addresses developments in energy access for different socio-economic groups (Daioglou et al., 2012; van Ruijven et al., 2012a).

In the LIMITS project, from which the scenario results are used in this study, no special attention was paid to Africa. Furthermore, development issues are not always properly addressed in the Integrated Assessment models used (Van Ruijven et al., 2008). These models were originally designed to address issues which are important for the energy systems in industrialized countries with full access to modern sources of energy and high levels of per capita income. As shown in our study, Africa's current energy system and future energy challenges are inherently different than in these industrialised countries.

Several relevant issues in the context of energy development in Africa are not covered by the models. For instance, the $\mathrm{CO}_{2}$ 
emissions from traditional biomass use are assumed to be zero in the different models. However, this assumption is only true for sustainably harvested biomass, while globally only around $60 \%$ of traditional biomass is estimated to be produced sustainably (Bailis et al., 2005; Reddy and Balachandra, 2006). As a result, the current energy-related $\mathrm{CO}_{2}$ emissions are probably an underestimation of the actual values (see also Daioglou et al. (2012)). Furthermore, as traditional biomass use is more common in Africa than in other parts of the world, also the African share in global energy-related $\mathrm{CO}_{2}$ emissions may be an underestimation. On the longer term, energy-related $\mathrm{CO}_{2}$ emissions will converge towards the values presented in this paper, as traditional biomass use will slowly phase out. As a result, the 2010-2100 emission growth rate is probably overestimated, although still significant and much higher than in other world regions due to the huge increase in fossil fuel use, while Africa's share in global $\mathrm{CO}_{2}$ emissions in 2100 remains moreover unaffected.

Urbanisation is another relevant issue. It plays an important role in the household fuel choice in Africa and related $\mathrm{CO}_{2}$ emissions, as fuelwood forms the dominant choice in rural areas and charcoal in urban areas. Most models, however, do not include differences in urban and rural developments. Moreover, traditional biomass is often represented as one energy source, despite large differences between fuelwood and charcoal concerning the impacts on deforestation and related $\mathrm{CO}_{2}$ emissions. ${ }^{14}$ As charcoal production is generally associated with much higher $\mathrm{CO}_{2}$ emissions than fuelwood, a slow transition to modern fuel use combined with expected rapid urbanisation (UNDESA, 2014) could lead to a much higher increase in energy-related $\mathrm{CO}_{2}$ emissions than is presented in this paper.

Another issue that is poorly covered in the models used is the informal sector, which is relatively large in Africa (Schneider et al., 2010). One aspect of economic growth in developing countries is the monetization of the currently non-marketed sources. This implies that in real terms, activities would be growing less than suggested by the per capita GDP growth presented in Fig. 1. Several models try to capture this effect by using GDP expressed in Purchasing Power Parity (PPP) to drive their energy demand and technology development. However, the relation between PPP and the informal economy is only barely understood (Van Vuuren and Alfsen, 2006; Van Ruijven et al., 2008).

A fourth issue that is not covered in most models is energy infrastructure like high and medium voltage lines. The level of energy infrastructure in Africa is currently very low (Foster and Briceño-Garmendia, 2010). However, to support the projected rapid demand for electricity services, related rapid expansion of its infrastructure is required, with relatively large related costs (van Ruijven et al., 2012a; Panos et al., 2015). The models implicitly assume that the electricity is transported through a grid, while most models do not account for their costs. Furthermore, the people living in thinly populated areas that currently lack access to electricity might be more cost-effectively served through minigrids or off-grid solutions (Szabo et al., 2011).

\section{Conclusions and policy implications}

In this paper we have discussed Africa's role in global energy developments in the 21st century without and with globally

\footnotetext{
${ }^{14}$ Fuelwood consumption is typically a non-commercial, local activity so that consumers can tailor their behaviour to local production rates. Charcoal, on the other hand, is a commercial activity; it is typically transported long distances so that consumers are far-removed from production zones and pricing mechanisms are not in place to adequately reflect supply scarcity. In addition, charcoal is frequently associated with clearance for crop cultivation.
}

coordinated climate policy. The analysis is based on the results of a recent multi-model scenario study. The use of multiple models allows to assess the robustness of the projected developments. The models often agree in terms of overall trends, but show quite some differences in absolute numbers, pointing at significant uncertainties. The following conclusions are drawn from the analysis:

\subsection{Africa's share in global energy-related $\mathrm{CO}_{2}$ emissions is projected to increase significantly}

The commercial energy system in Africa (especially in Sub-Saharan Africa) is currently still in its infancy, with low levels of electrification and many people using solid fuels for cooking and heating. However, current business-as-usual scenarios project large population growth and strong economic development. Based on these expectations, the models used in this paper project an enormous increase in demand for energy services. The models also show that without climate policy, this increase in demand will most likely be supplied by fossil energy sources. As a result, Africa's energy-related $\mathrm{CO}_{2}$ emissions are expected to increase by a factor 7 to 50 between 2010 and 2100, which is much faster than projected globally. As a result, Africa's share in global energy-related $\mathrm{CO}_{2}$ emissions is projected to increase from 1-4\% in 2010 to $3-23 \%$ in 2100 , with emissions starting to become really significant on a global scale only after 2050 .

5.2. In order to reach stringent long-term climate targets such as the $2{ }^{\circ} \mathrm{C}$ target, mitigation effort in Africa is already important in the medium term

As part of the global coordinated climate policy that aims for reaching the $2{ }^{\circ} \mathrm{C}$ target, the models project a phase out of fossil fuel use without CCS and an expansion of the energy system through the use of non-biomass renewables and bio-energy with and without CCS. The shares of Nuclear energy and fossil CCS remain marginal compared to other world regions. Emissions are projected to peak between 2020 and 2060 and go negative between 2040 and 2090. At the same time, the models project a rapid expansion of Africa's industrial and power sectors throughout the century. As energy-system investments have a lasting impact (generally 30-60 years), the period of rapid expansion is of key importance for climate mitigation, which is well before 2050 . An important challenge is to align the increasing investments in the energy system with climate policy and potential revenues from international carbon trading.

\subsection{Universal energy access by 2030 is unlikely to be achieved without targeted policies}

The models project that by 2030 , on average, still around $50 \%$ of total household energy use is supplied through traditional biomass and installed electricity capacity is well below current levels in China. These conclusions are in line with the earlier findings of Calvin et al. (2013) and Panos et al. (2015). These trends conclude that ensuring universal access to electricity and modern fuels for cooking and heating by 2030 - as targeted under the UN Secretary General's Sustainable Energy for All initiative and the Sustainable Development Goals - is unlikely to be achieved without additional targeted policies, including the creation of well-functioning markets for modern energy sources and an effective investment climate to build the required electricity infrastructure.

5.4. Africa's rapid growth in demand for energy services could imply that its role as a net fossil fuel exporter diminishes over time

Based on current exports and agricultural potentials, a common perception is that Africa could become increasingly important for 
global energy supply for both fossil fuels (especially oil and gas) and bio-energy. However, especially for fossil fuels, currently this only holds for a couple of countries with large oil and gas resources like Nigeria, Algeria and Libya, while most other countries are net energy importers. Furthermore, the models analysis concludes that the existing proven reserves are likely to be insufficient to meet projected demand. Although there are substantial additional resources, these resources are generally expensive and may have to compete with less expensive reserves in other world regions. It should be noted that the models do not fully account for the large natural gas discoveries before the coast of Mozambique and Tanzania that could significantly increase African export far beyond the current projections. Nevertheless, many African countries still face the choice between investing more heavily in the exploration and extraction of fossil fuel resources, importing fossil fuels from other world regions, or becoming independent from fossil fuels by making the transition towards more renewable energy resources in their energy mix. Global climate policy could help to make this transition.

The analysis also points at significant uncertainties, related among others to differences in data and model dynamics. Furthermore, several relevant issues in the context of energy developments in Africa are not properly addressed in the models, including the emissions related to the use of traditional biomass, urbanisation, the informal sector and infrastructure development. To address these issues, a dedicated model inter-comparison study for Africa, modelled along the lines of the Asian Modelling Exercise (AME; Calvin et al., 2012) and the CLIMACAP-LAMP project for Latin America (Calvin, 2013; van der Zwaan et al., forthcoming), could further explain and narrow the large ranges in model projections and guide important model developments and data updates.

\section{Acknowledgements}

The research presented in this paper was funded by the Dutch ministry of Foreign Affairs, Directorate General of Trade and International Cooperation and builds on the massive volume of work carried out in the LIMITS project, funded from the European Union Seventh Framework Programme FP7/2007-2013 under grant agreement no. 282846.

\section{References}

Alton, T., Arndt, C., Davies, R., Hartley, F., Makrelov, K., Thurlow, J., Ubogu, D., 2014 Introducing carbon taxes in South Africa. Appl. Energy 116, 344-354. http://dx. doi.org/10.1016/j.apenergy.2013.11.034.

Bacon, R., Mattar, A., 2005. The Vulnerability of African Countries to Oil Price Shocks: Major Factors and Policy Options - The case of Oil Importing Countries. World Bank, Washington D.C..

Bailis, R., Ezzati, M., Kammen, D.M., 2005. Mortality and greenhouse gas impacts of biomass and petroleum energy futures in Africa. Science 308 (5718), 98-103. http://dx.doi.org/10.2307/3841403.

Bazilian, M., Nussbaumer, P., Rogner, H.-H., Brew-Hammond, A., Foster, V., Pachauri, S., Williams, E., Howells, M., Niyongabo, P., Musaba, L., Gallachóir, B.Ó., Radka, M., Kammen, D.M., 2012. Energy access scenarios to 2030 for the power sector in sub-Saharan Africa. Util. Policy 20 (1), 1-16. http://dx.doi.org/10.1016/j. jup.2011.11.002.

BGR, 2013. Energy study 2013. Reserves, Resources and Availability of Energy Resources. Federal Institute for Geosciences and Natural Resources (BGR), Hannover, Germany.

Boden, T.A., Marland, G., Andres, R.J., 2011. Global, Regional, and National FossilFuel $\mathrm{CO}_{2}$ Emissions. Carbon Dioxide Information Analysis Center (CDIAC), Oak Ridge National Laboratory, U.S. Department of Energy, Oak Ridge, Tennessee.

Bosetti, V., Carraro, C., Galeotti, M., Massetti, E., Tavoni, M., 2006. A world induced technical change hybrid model. Energy J. 27, 13-38.

Bosetti, V., Tavoni, M., De Cian, E., Sgobbi, A., 2009. The 2008 WITCH Model: New Model Features and Baseline. Fondazione Eni Enrico Mattei, Venezia, Italy.

Brew-Hammond, A., 2010. Energy access in Africa: challenges ahead. Energy Policy 38 (5), 2291-2301. http://dx.doi.org/10.1016/j.enpol.2009.12.016.
Calvin, K., Clarke, L., Krey, V., Blanford, G.J., Jiang, K., Kainuma, M., Kriegler, E., Luderer, G., Shukla, P.R., 2012. The role of asia in mitigating climate change: results from the asia modeling exercise. Energy Econ. 34 (Suppl. 3), S251-S260. http://dx.doi.org/10.1016/j.eneco.2012.09.003.

Calvin, K., 2013. The Latin American Modeling Project (LAMP). Presented at the CESM SDWG Meeting (19 February 2013). 〈http://www.cesm.ucar.edu/work ing_groups/Societal/Presentations/13/calvin.pdf).

Calvin, K.V., Pachauri, S., De Cian, E., Mouratiadou, I., 2013. The effect of African growth on future global energy, emissions, and regional development. Clim. Change . http://dx.doi.org/10.1007/s10584-013-0964-4.

Calvin, K.V.e.a., 2011. GCAM Wiki Documentation, Wikipedia. 〈https://wiki.umd. edu/gcam/ $/$.

Canadell, J.G., Raupach, M.R., Houghton, R.A., 2009. Anthropogenic $\mathrm{CO}_{2}$ emissions in Africa. Biogeosciences 6 (3), 463-468. http://dx.doi.org/10.5194/bg-6-463-2009.

Chaturvedi, V., Waldhoff, S., Clarke, L., Fujimori, S., 2012. What are the starting points? Evaluating base-year assumptions in the Asian Modeling Exercise. Energy Econ. 34 (Suppl. 3), S261-S271. http://dx.doi.org/10.1016/j. eneco.2012.05.004.

Clarke, L., Krey, V., Weyant, J., Chaturvedi, V., 2012. Regional energy system variation in global models: results from the Asian Modeling Exercise scenarios. Energy Econ. 34 (Suppl. 3), S293-S305. http://dx.doi.org/10.1016/j. eneco.2012.07.018.

Collier, P. 2010. The Plundered Planet: Why We Must - and How We Can - Manage Nature for Global Prosperity. Oxford University Press, New York.

Daioglou, V., van Ruijven, B.J., van Vuuren, D.P., 2012. Model projections for household energy use in developing countries. Energy 37 (1), 601-615. http: //dx.doi.org/10.1016/j.energy.2011.10.044.

Desai, M.A., Mehta, S., Smith, K.R., 2004. Indoor smoke from solid fuels: assessing the environmental burden of disease at national and local levels. In: PrüssÜstün Annette, D.C.-L., Carlos, Corvalán, Alistair, Woodward (Eds.), Environmental Burden of Disease No. 4. WHO, Geneva, Switzerland.

Ekholm, T., Krey, V., Pachauri, S., Riahi, K., 2010. Determinants of household energy consumption in India. Energy Policy 38 (10), 5696-5707. http://dx.doi.org/ 10.1016/j.enpol.2010.05.017.

Foster, V., Briceño-Garmendia, C. (Eds.), 2010. Africa's Infrastructure: a Time for Transformation. Worldbank, Washington, DC.

Gambhir, A., Schulz, N., Napp, T., Tong, D., Munuera, L., Faist, M., Riahi, K., 2013. A hybrid modelling approach to develop scenarios for China's carbon dioxide emissions to 2050. Energy Policy 59 (0), 614-632. http://dx.doi.org/10.1016/j. enpol.2013.04.022.

Gerland, P., Raftery, A.E., Sevčíková, H., Li, N., Gu, D., Spoorenberg, T., Alkema, L., Fosdick, B.K., Chunn, J., Lalic, N., Bay, G., Buettner, T., Heilig, G.K., Wilmoth, J., 2014. World population stabilization unlikely this century. Science 346 (6206), 234-237. http://dx.doi.org/10.1126/science.1257469.

Gujba, H., Mulugetta, Y., Azapagic, A., 2011. Power generation scenarios for Nigeria: an environmental and cost assessment. Energy Policy 39 (2), 968-980. http: //dx.doi.org/10.1016/j.enpol.2010.11.024.

Hutton, G., Rehfuess, E., Tediosi, F., 2007. Evaluation of the costs and benefits of interventions to reduce indoor air pollution. Energy Sustain. Dev. 11 (4), 34-43. http://dx.doi.org/10.1016/S0973-0826(08)60408-1.

IEA, 2010. World Energy Outlook 2010. International Energy Agency, Paris.

IEA, 2011. World Energy Outlook 2011. International Energy Agency, Paris.

IEA, 2012. World Energy Outlook 2012. International Energy Agency, Paris.

IEA, 2014. Africa Energy Outlook. A Focus on Energy Prospects in Sub-Saharan Africa. World Energy Outlook Special report. International Energy Agency, Paris, France.

IRENA, 2011. Scenarios and Strategies for Africa. Working paper presented at the IRENA-Africa high-level consultations held on 8 and 9 July 2011 in Abu Dhabi, UEA. International Renewable Energy Agency (IRENA).

IRENA, 2012. Prospects for the African Power Sector. Scenarios and Strategies for Africa Project. International Renewable Energy Agency (IRENA), Abu Dhabi, United Arab Emerates.

Johansson, D.J.A., Lucas, P.L., Weitzel, M., Ahlgren, E.O., Bazaz, A.B., Chen, W., den Elzen, M.G.J., Ghosh, J., Grahn, M., Liang, Q.-M., Peterson, S., Pradhan, B.K., van Ruijven, B.J., Shukla, P.R., van Vuuren, D.P., Wei, Y.M., 2014. Multi-model comparison of the economic and energy implications for China and India in an international climate regime. Mitig. Adapt. Strateg. Global Change, 1-25. http: //dx.doi.org/10.1007/s11027-014-9549-4.

Kaya, Y., 1990. Impact of Carbon Dioxide Emission Control on GNP Growth: Interpretation of Proposed Scenarios. Response Strategies Working Group, Paris (mimeo).

Keppo, I., van der Zwaan, B., 2012. The impact of uncertainty in climate targets and $\mathrm{CO}_{2}$ storage availability on long-term emissions abatement. Environ. Model. Assess. 17 (1-2), 177-191. http://dx.doi.org/10.1007/s10666-011-9283-1.

Knopf, B., Chen, Y.-H.H., De Cian, E., Förster, H., Kanudia, A., Karkatsouli, I., Keppo, I., Koljonen, T., Schumacher, K., van Vuuren, D.P., 2013. Beyond 2020-Strategies and costs for transforming the European energy system. Clim. Change Econ. 4 (1), 1340001. http://dx.doi.org/10.1142/S2010007813400010.

Kober, T., van der Zwaan, B., Rösler, H., 2014. Emission certficate trade and costs under regional burden-sharing regimes for a $2{ }^{\circ} \mathrm{C}$ climate change control target Clim. Change Econ. 5 (1), 1440001. http://dx.doi.org/10.1142/ S2010007814400016.

Kriegler, E., Tavoni, M., Aboumahboub, T., Luderer, G., Calvin, K., DeMaere, G., Krey, V., Riahi, K., Rösler, H., Schaeffer, M., van Vuuren, D.P., 2013a. What does the $2{ }^{\circ} \mathrm{C}$ target imply for a global climate agreement in 2020? The LIMITS study on Durban Platform scenarios. Clim. Change Econ. 4 (4), 1340008. http://dx.doi. org/10.1142/S2010007813400083. 
Kriegler, E., Tavoni, M., Riahi, K., van Vuuren, D.P., 2013b. Introducing the LIMITS special issue-implementing climate policies in the major economies: an assessment of Durban platform architectures. Clim. Change Econ. 4 (4), 1302002. http://dx.doi.org/10.1142/S2010007813020028.

Kriegler, E., Weyant, J., Blanford, G., Krey, V., Clarke, L., Edmonds, J., Fawcett, A. Luderer, G., Riahi, K., Richels, R., Rose, S., Tavoni, M., Vuuren, D., 2014. The role of technology for achieving climate policy objectives: overview of the EMF 27 study on global technology and climate policy strategies. Clim. Change 123 (34), 353-367. http://dx.doi.org/10.1007/s10584-013-0953-7.

Liousse, C., Assamoi, E., Criqui, P., Granier, C., Rosset, R., 2014. Explosive growth in African combustion emissions from 2005 to 2030. Environ. Res. Lett. 9, 035003. http://dx.doi.org/10.1088/1748-9326/9/3/035003.

Lucas, P.L., Shukla, P.R., Chen, W., van Ruijven, B.J., Dhar, S., den Elzen, M.G.J., van Vuuren, D.P., 2013. Implications of the international reduction pledges on long term energy system changes and costs in China and India. Energy Policy 63, 1032-1041. http://dx.doi.org/10.1016/j.enpol.2013.09.026.

Luderer., G., Leimbach, M., Bauer, N., Kriegler, E., 2011. Description of the ReMIND-R Model.

Mandelli, S., Barbieri, J., Mattarolo, L., Colombo, E., 2014. Sustainable energy in Africa: a comprehensive data and policies review. Renew. Sustain. Energy Rev. 37, 656-686. http://dx.doi.org/10.1016/j.rser.2014.05.069.

McCollum, D., Nagai, Y., Riahi, K., Marangoni, G., Calvin, K., Pietzcker, R., van Vliet, J., van der Zwaan, B., 2013. Energy investments under climate policy: a comparison of global models. Clim. Change Econ. 4 (4), 1340010. http://dx.doi.org 10.1142/S2010007813400101.

McCollum, D., Bauer, N., Calvin, K., Kitous, A., Riahi, K., 2014. Fossil resource and energy security dynamics in conventional and carbon-constrained worlds. Clim. Change 123 (3-4), 413-426. http://dx.doi.org/10.1007/s10584-013-0939-5.

Meinshausen, M., Hare, B., Wigley, T.M.L., Van Vuuren, D., Den Elzen, M.G.J., Swart, R., 2006. Multi-gas emissions pathways to meet climate targets. Clim. Change 75 (1-2), 151-194.

Nilsson, M., Lucas, P.L., Yoshida, T., 2013. Towards an integrated framework for SDGs: ultimate and enabling goals for the case of energy. Sustainability 5 (10) 4124-4151. http://dx.doi.org/10.3390/su50x000x.

Pachauri, S., van Ruijven, B.J., Nagai, Y., Riahi, K., van Vuuren, D.P., Brew-Hammond, A., Nakicenovic, N., 2013. Pathways to achieve universal household access to modern energy by 2030. Environ. Res. Lett. 8 (2), 024015.

Panos, E., Turton, H., Densing, M., Volkart, K., 2015. Powering the growth of SubSaharan Africa: the Jazz and Symphony scenarios of World Energy Council. Energy Sustain. Dev. 26 (0), 14-33. http://dx.doi.org/10.1016/j.esd.2015.01.004.

Reddy, B.S., Balachandra, P., 2006. Climate change mitigation and business opportunities - the case of the household sector in India. Energy Sustain. Dev. 10 (4), 59-73. http://dx.doi.org/10.1016/S0973-0826(08)60556-6.

Riahi, K., Grübler, A., Nakicenovic, N., 2007. Scenarios of long-term socio-economic and environmental development under climate stabilization. Technol. Forecast. Soc. Change 74 (7), 887-935.

Riahi, K., Dentener, F., Gielen, D., Grubler, A., Jewell, J., Klimont, Z., Krey, V. McCollum, D., Pachauri, S., Rao, S., van Ruijven, B., van Vuuren, D.P., Wilson, C. 2012. Chapter 17 - Energy Pathways for Sustainable Development, Global Energy Assessment - Toward a Sustainable Future. Cambridge University Press Cambridge, UK and New York, NY, USA and the International Institute for Applied Systems Analysis, Laxenburg, Austria, pp. 1203-1306.

Riahi, K., Kriegler, E., Johnson, N., Bertram, C., den Elzen, M., Eom, J., Schaeffer, M. Edmonds, J., Isaac, M., Krey, V., Longden, T., Luderer, G., Méjean, A., McCollum, D.L., Mima, S., Turton, H., van Vuuren, D.P., Wada, K., Bosetti, V., Capros, P., Criqui, P., Hamdi-Cherif, M., Kainuma, M., Edenhofer, O., 2014. Locked into Copenhagen pledges - implications of short-term emission targets for the cost and feasibility of long-term climate goals. Technol. Forecast. Soc. Change $90(0)$ 8-23. http://dx.doi.org/10.1016/j.techfore.2013.09.016.

Rogelj, J., Hare, W., Lowe, J., van Vuuren, D.P., Riahi, K., Matthews, B., Hanaoka, T., Jiang, K., Meinshausen, M., 2011. Emission pathways consistent with a $2{ }^{\circ} \mathrm{C}$ global temperature limit. Nat. Clim. Change 1; , pp. 413-418. http://dx.doi.org/ 10.1038/nclimate1258.

Rogner, H.-H., Aguilera, R.F., Archer, C., Bertani, R., Bhattacharya, S.C., Dusseault, M. B., Gagnon, L., Haberl, H., Hoogwijk, M., Johnson, A., Rogner, M.L., Wagner, H., Yakushev, V., 2012. Chapter 7 - Energy Resources and Potentials, Global Energy Assessment - Toward a Sustainable Future. Cambridge University Press Cambridge, UK and New York, NY, USA and the International Institute for Applied Systems Analysis, Laxenburg, Austria, pp. 423-512.

Rösler, H., van der Zwaan, B., Keppo, I., Bruggink, J., 2014. Electricity versus hydrogen for passenger cars under stringent climate change control. Sustain. Energy Technol. Assess. 5 (0), 106-118. http://dx.doi.org/10.1016/j. seta.2013.11.006.

Schneider, F., Buehn, A., Montenegro, C.E., 2010. New estimates for the shadow economies all over the World. Int. Econ. J. 24 (4), 443-461. http://dx.doi.org/ $10.1080 / 101687372010.525974$.

Steckel, J.C., Jakob, M., Marschinski, R., Luderer, G., 2011. From carbonization to decarbonization?-Past trends and future scenarios for China's $\mathrm{CO}_{2}$ emissions. Energy Policy 39 (6), 3443-3455. http://dx.doi.org/10.1016/j.enpol.2011.03.042.

Stehfest, E., van Vuuren, D.P., Kram, T., Bouwman, L., Alkemade, R., Bakkenes, M., Biemans, H., Bouwman, A., den Elzen, M., Janse, J., Lucas, P., van Minnen, J., Müller, M., Prins, A., 2014. Integrated Assessment of Global Environmental
Change with IMAGE 3.0. PBL Netherlands Environmental Assessment Agency The Hague, The Netherlands.

Szabo, S., Bódis, K., Huld, T., Moner-Girona, M., 2011. Energy solutions in rural Africa: mapping electrification costs of distributed solar and diesel generation versus grid extension. Environ. Res. Lett. 6 (3), 034002.

Tavoni, M., Kriegler, E., Aboumahboub, T., Calvin, K., De Maere, G., Jewell, J., Kober T., Lucas, P.L., Luderer, G., McCollum, D., Marangoni, G., Riahi, K., van Vuuren, D. P., 2013. The distribution of the major economies' effort in the Durban platform scenarios. Clim. Change Econ. 4 (4), 1340009. http://dx.doi.org/10.1142/ S2010007813400095.

UN, 2013. Composition of Macro Geographical (Continental) Regions, Geographical Sub-regions, and Selected Economic and Other Groupings. United Nations Statistics Division (Accessed 13.06.14).

UN, 2015. Transforing our world: The 2030 agenda for sustainable development. UN, New York.

UNCTAD, 2012. Economic Development in Africa Report 2012: Structural transformation and Sustainable Development in Africa. United Nations Conference on Trade And Development, New York and Geneva.

UNDESA, 2013. World Population Prospects: The 2012 Revision. Population Division of the Department of Economic and Social Affairs of the United Nations Secretariat, New York.

UNDESA, 2014. World Urbanization Prospects: the 2014 Revision. Population Division of the Department of Economic and Social Affairs of the United Nations Secretariat, New York.

UNECA, 2011. Fossil fuels in Africa in the Context of a Carbon Constrained World United Nations Economic Commission for Africa (UNECA), African Climate Policy Centre (ACPC).

UNFCCC, 2009. Copenhagen Accord, Draft decision COP15. 〈http://unfccc.int/re source/docs/2009/cop15/eng/107.pdf (Retrieved from 15.03.10)

UNFCCC, 2010a. Information Provided by Parties Relating to Appendix II of the Copenhagen Accord. 〈http://unfccc.int/home/items/5264.php〉 (Retrieved from 15.03.10).

UNFCCC, 2010b. Information Provided by Parties Relating to Appendix I of the Copenhagen Accord. 〈http://unfccc.int/home/items/5264.php〉 (Retrieved from 15.03.10).

UNFCCC, 2013. Compilation of information on nationally appropriate mitigation actions to be implemented by developing country parties. United Nations Framework Convention on Climate Change, Bonn, document FCCC/SBI/2013/ INF.

van der Zwaan, B., 2013. The role of nuclear power in mitigating emissions from electricity generation. Energy Strategy Rev. 1 (4), 296-301. http://dx.doi.org/ 10.1016/j.esr.2012.12.008.

van der Zwaan, B., Rösler, H., Kober, T., Aboumahboub, T., Calvin, K., Gernaat, D. Marangoni, G., McCollum, D., 2013. A cross-model comparison of global longterm technology diffusion under a $2{ }^{\circ} \mathrm{C}$ climate change control target. Clim. Change Econ. 4 (4), 1340013. http://dx.doi.org/10.1142/S2010007813400137.

van der Zwaan, B., Calvin, K., Clarke, L., 2015. Climate Mitigation in Latin America: implications for energy and land use. Introduction to the Special Issue on the findings of the CLIMACAP-LAMP project. Energy Econ.

Van Ruijven, B.J., Urban, F., Benders, R.M.J., Moll, H.C., van der Sluijs, J.P., van Vuuren, D.P., de Vries, H.J.M., 2008. Modeling energy and development: an evaluation of models and concepts. World Dev. 36 (12), 2801-2821. http://dx.doi.org/ 10.1016/j.worlddev.2008.01.011.

van Ruijven, B.J., Schers, J., van Vuuren, D.P., 2012a. Model-based scenarios for rural electrification in developing countries. Energy 38 (1), 386-397. http://dx.doi. org/10.1016/j.energy.2011.11.037.

Van Ruijven, B.J., van Vuuren, D.P., van Vliet, J., Mendoza Beltran, A., Deetman, S. den Elzen, M.G.J., 2012b. Implications of greenhouse gas emission mitigation scenarios for the main Asian regions. Energy Econ. 34 (Suppl. 3), S459-S469. http://dx.doi.org/10.1016/j.eneco.2012.03.013.

Van Sluisveld, M.A.E., Gernaat, D.E.H.J., Ashina, S., Calvin, K.V., Garg, A., Isaac, M., Lucas, P.L., Mouratiadou, I., Otto, S.A.C., Rao, S., Shukla, P.R., van Vliet, J., van Vuuren, D.P., 2013. A multi-model analysis of post-2020 mitigation efforts of five major economies. Clim. Change Econ. 4 (4), 1340012. http://dx.doi.org/ 10.1142/S2010007813400125.

Van Vuuren, D., Alfsen, K., 2006. PPP versus mer: searching for answers in a multidimensional debate. Clim. Change 75 (1-2), 47-57. http://dx.doi.org/10.1007/ s10584-005-9045-7.

van Vuuren, D.P., 2007. Energy systems and climate policy-Long-term scenarios for an uncertain future, science, technology and society. Utrecht University, Utrecht.

van Vuuren, D.P., den Elzen, M.G.J., van Vliet, J., Kram, T., Lucas, P., Isaac, M., 2009 Comparison of different climate regimes: the impact of broadening participation. Energy Policy 37 (12), 5351-5362. http://dx.doi.org/10.1016/j. enpol.2009.07.058.

Winkler, H., Hughes, A., Marquard, A., Haw, M., Merven, B., 2011. South Africa's greenhouse gas emissions under business-as-usual: The technical basis of 'Growth without Constraints' in the Long-Term Mitigation Scenarios. Energy Policy 39 (10), 5818-5828. http://dx.doi.org/10.1016/j.enpol.2011.06.009.

Yumkella, K., Holliday, C., 2012. Sustainable Energy for All: a Global Action Agenda, Pathways for Concerted Action toward Sustainable Energy for All. The Secretary-General's High-Level Group on Sustainable Energy for All, New York. 